Int. J. Odontostomat., 4(3):303-308, 2010.

\title{
Cytotoxicity of Dental Alginates
}

\author{
Citotoxicidad de Alginatos Dentales
}

Matheus Melo Pithon*; Rogério Lacerda dos Santos*; Fernanda Otaviano Martins ${ }^{\star *}$ \& Maria Teresa Villela Romanos ${ }^{\star * *}$

PITHON, M. M.; DOS SANTOS, R. L.; MARTINS, F. O. \& ROMANOS, M. T. V. Cytotoxicity of dental alginates. Int. J. Odontostomat., 4(3):303-308, 2010.

ABSTRACT: Alginate, or irreversible hydrocolloid, is one of the most accepted impression materials used in dentistry. However, some substances existing in these materials can be toxic. The aim of this study was to assess the cytotoxicity of alginates for dental applications. Fourteen different alginates were assessed: Jeltrate, Jeltrate Plus, Jeltrate Chromatic, Alga Gel, Printer Gel, Ava Gel, New Print, Kromopan 100, Tropicalgin, Cavex Orthotrace, Hydrogum, Orthoprint, Cavex Color Change, and Qualitygel. Three control groups were also used in this study: positive control group $(\mathrm{C}+)$ consisting of cell detergent Tween 80, negative control group (C-) consisting of PBS, and cell control group (CC) consisting of non-exposed cells. After manipulating the materials according to the manufacturer's instructions, samples were made by using silicone rings. Next, the samples were immersed into Eagle's minimum essential medium (MEM) for 2 minutes followed by removal of supernatants and contact with L929 fibroblasts. After contact with the medium, the cells were incubated for further 24 hours in which $100 \mu \mathrm{l}$ of $0.01 \%$ neutral red stain were added. Cells were incubated again for 3 hours so that the stain could be absorbed. After this period, the cells were fixed and viable cell counting was performed by using a spectrophotometer (BioTek, Winooski, Vermont, USA) at wavelength of $492 \mathrm{~nm}$. The results demonstrated statistical differences between CC and $C$ - groups in relation to other ones $(p<0.05)$. No statistical differences were observed between Jeltrate Plus and Hydrogum groups, between Jeltrate and Jeltrate Chromatic, Printer Gel, Tropicalgin, and Qualitygel groups, and between Jeltrate Chromatic and Alga Gel, Ava Gel, New Print, Kromopan 100, Cavex Orthotrace, Hydrogum, Orhtoprint, and Cavex Color Change groups. One can conclude, based on the results of this study, that all alginate materials were found to be cytotoxic.

KEY WORDS: cytotoxicity, dental impression materials, cell culture techniques.

\section{INTRODUCTION}

Alginate is an impression material classified as an irreversible hydrocolloid that is easy to handle, allowing good detail reproducibility in addition to being cheap and comfortable for the patient (Anusavice, 2005). Therefore, such a material is largely used in dentistry. However, despite its easy manipulation, perfect dental impressions using alginate are not always achieved by non-experienced students, thus often requiring repeated procedures (Samuel et al., 1995).

Nevertheless, it is known that some heavy metals and silica particles can comprise the alginate powder and cause some risk of toxicity for both practitioner and/or patient. Amongst these metals, one can cite the lead, which is present in the alginate powders to improve their elastic properties following gelification despite sometimes being found as an impurity (Braga et al., 2007).

Basically, intoxication with alginate occurs through inhalation of the powder by patient and practitioner, accidental intake by the patient, and absorption by oral mucosa in the cases of repeated impression procedures (Braga et al., 2005; Braga et al., 2007; Sydiskis \& Gerhardt, 1993).

During the impression procedure, alginate is left in close contact with the oral mucosa for approximately

\footnotetext{
Specialist in Orthodontics and Master in Orthodontics, Federal University of Rio de Janeiro (UFRJ), Brazil; Doctorate Student in Orthodontics, Federal University of Rio de Janeiro (UFRJ), Brazil.

* Graduate Student in Microbiology and Immunology, Federal University of Rio de Janeiro (UFRJ), Brazil; Trainee at the Prof. Paulo de Goés Institute of Microbiology, Federal University of Rio de Janeiro (UFRJ), Brazil.

${ }^{* * *}$ Doctor in Microbiology and Immunology, Federal University of Rio de Janeiro (UFRJ), Brazil; Adjunct Professor, Federal University of Rio de Janeiro - UFRJ, Brazil.
} 
2 minutes, and this tissue is highly vascularised and has great absorption potential. Therefore, repeated impression procedures might cause a certain degree of cytotoxicity to the patient depending on the material composition (Braga et al., 2007; Samuel et al.).

Alginates differ from each other according to the components present in their formulation. Based on this premise, the objective of the present study was to assess the cytotoxicity in cell cultures using different alginate materials for dental application and to verify the hypothesis that different alginate formulations promote different cell reactions.

\section{MATERIAL AND METHOD}

Cell Culture. The cell line used for this study was mouse L929 fibroblasts obtained from the American Type Culture Collection (TCC, Rockville, MD) and cultivated in Eagle's minimum essential medium (MEM) (Cultilab, Campinas, São Paulo, Brazil). The cell culture was supplemented with $2 \mathrm{mM}$ of L-glutamine (Sigma, St. Louis, Missouri, USA), $50 \mathrm{mg} / \mathrm{ml}$ of gentamicin (Schering Plough, Kenilworth, New Jersey, USA), 2.5 $\mathrm{mg} / \mathrm{ml}$ of fungizone (Bristol-Myers-Squib, New York, USA), $0.25 \mathrm{mM}$ of sodium bicarbonate solution (Merck, Darmstadt, Germany), $10 \mathrm{mM}$ of HEPES (Sigma, St. Louis, Missouri, USA), and $10 \%$ of foetal bovine serum (FBS) (Cultilab, Campinas, São Paulo, Brazil), then being kept at $370 \mathrm{C}$ in $5 \% \mathrm{CO}_{2}$ environment.

Alginates Studied. The total sample consisted of 14 dental alginates from different manufacturers and divided into 14 groups as follows: Jeltrate (Dentsply, Petrópolis, Brazil, Lot 971244), Jeltrate Plus (Dentsply, Petrópolis, Brazil, Lot 017484A), Jeltrate Chromatic (Dentsply, Petrópolis, Brazil, Lot 955069), Alga Gel (Tecknew, Rio de Janeiro, Brazil, Lot 08276), Printer Gel (Euronda, Magé, Brazil, Lot 012l06), Ava Gel (Dentsply, Petrópolis, Brazil, Lot 024471A), New Print (Tecknew, Rio de Janeiro, Brazil, Lot 08063), Kromopan 100 (Lascoal, Firenze, Italy, Lot 0157372182.105), Tropicalgin (Zhermack, Rovigo, Italy, Lot C302240), Cavex Orthotrace (Cavex, Neoderland, Lot 080910), Hydrogum (Zhermack, Rovigo, Italy, Lot C302025), Orthoprint (Zhermack, Rovigo, Italy, Lot 72251), Cavex Color Change (Cavex, Neoderland, Lot 080715), and Qualitygel (Quality Dent, São José dos Campos, Lot 654338).

Sample Preparation. For sample preparation, the ma- terial was manipulated during 1 minute by using rubber bowl and plastic spatula according to the manufacturer's recommendations. After adequate homogenization, the alginate was inserted into silicon rings (4 $\mathrm{mm}$ diameter x $4 \mathrm{~mm}$ height) until full gelification (Fig. 1).

Controls. To verify the cell response to extreme situations, other 3 groups were included in the study: Group CC (cell control), consisting of cells not exposed to any material; Group C+ (positive control), consisting of Tween 80 (Polioxietileno-20-Sorbitan); and Group C- (negative control), consisting PBS solution (Phosphate-buffered saline) in contact with the cells.

Assessing the Cytotoxity of the Materials. The materials were previously sterilized by exposing them to ultra-violet light (Labconco, Kansas, Missouri, USA) during 1 hour. Next, three samples of each material were placed in 24-wells plates containing Eagles' MEM (Cultilab, Campinas, São Paulo, Brazil). The culture medium was replaced with fresh medium every 24 hours, and the supernatants were collected after 24 , 48,72 , and 168 hours (7 days) for analysis of the toxicity to L929 cells. The supernatants were placed in a 96well plate containing a single layer of L929 cells and then incubated at $37^{\circ} \mathrm{C}$ for 24 hours in $5 \% \mathrm{CO}_{2}$ environment. After the incubation period, cell viability was determined using the "dye-uptake" technique described by Neyndorff et al. (1990), which was slightly modified. After the 24-hour incubation period, $100 \mu \mathrm{l}$ of $0.01 \%$ neutral-red staining solution (Sigma, St. Louis, Missouri, USA) were added to the medium within each well of the plates, and these were incubated for 3 hours at $37^{\circ} \mathrm{C}$ to allow the dye to penetrate into the living cells. After this period, the cells were fixed using $100 \mu \mathrm{l}$ of $4 \%$ formaldehyde solution (Reagen, Rio de Janeiro, Brazil)) in PBS (130 mM NaCl; $2 \mathrm{mM} \mathrm{KCl} ; 6 \mathrm{mM}$ $\mathrm{Na}_{2} \mathrm{HPO}_{4} 2 \mathrm{H}_{2} \mathrm{O} ; 1 \mathrm{mM} \mathrm{K}_{2} \mathrm{HPO}_{4}, \mathrm{pH}=7.2$ ) for 5 minutes. Next, $100 \mu \mathrm{l}$ of $1 \%$ acetic acid solution (Vetec, Rio de Janeiro, Brazil) with $50 \%$ methanol (Reagen, Rio de Janeiro, Brazil) were added to the medium to remove the dye. Absorption was measured after 20 minutes by using a spectrophotometer (BioTek, Winooski, Vermont, USA) at a wave length of $492 \mathrm{~nm}$.

Statistical Analysis. Statistical analysis were performed by using a SPSS v.13.0 software (SPSS Inc., Chicago, USA), and means and standard deviations were calculated for descriptive statistical analysis. The values for the amount of viable cells were submitted to analysis of variance (ANOVA) to determine whether statistical differences existed between the groups, and Tukey's test was applied thereafter. 


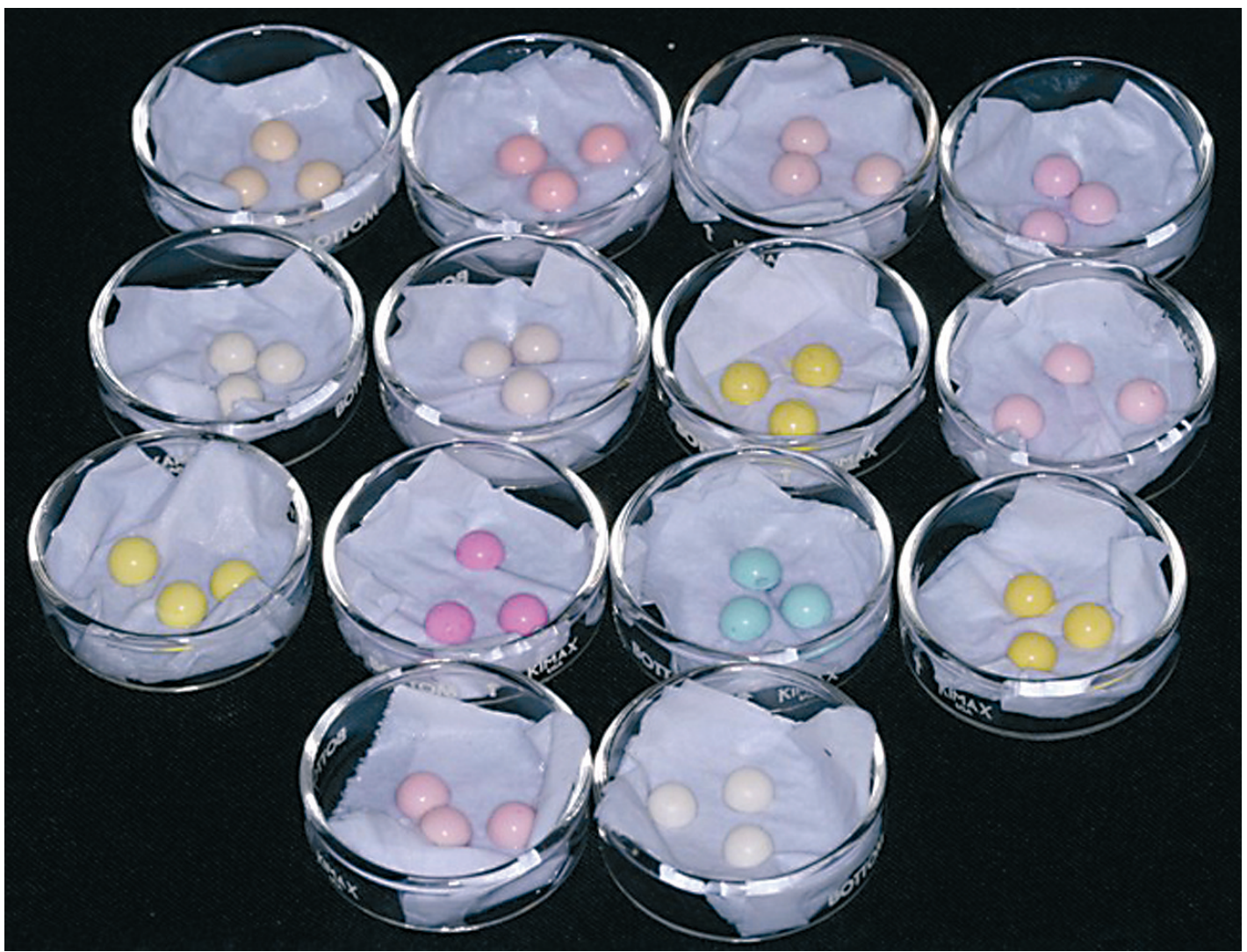

Fig 1. Samples prepared prior to cytotoxicity assessment.

\section{RESULTS}

The results showed no statistical differences between Jeltrate Plus and Hydrogum groups, between Jeltrate and Jeltrate Chromatic, Printer Gel, Tropicalgin, and Qualitygel groups, and between Jeltrate Chromatic and Alga Gel, Ava Gel, New Print, Kromopan 100, Cavex Orthotrace, Hydrogum, Orhtoprint, and Cavex Color Change groups (Table I).

On the other hand, there were statistical differences between $\mathrm{CC}$ and $\mathrm{C}$ - groups in relation to other ones.

With regard to cell viability, Jeltrate Plus was the material showing the highest percentage of viable cells compared to other groups, followed by Hydrogum (51.1\%), Orthoprint (48.4\%), New Print (46.2\%), Kromopan 100 (44.2\%), Cavex Orthotrace (44\%), Cavex Color Change (43.9\%), Ava Gel (42.8\%), Alga Gel (41.6\%), Jeltrate Chromatic (38\%), Printer Gel (30.4\%), Tropicalgin $(27,1 \%)$, Jeltrate $(26.3 \%)$, and Qualitygel $(25 \%)$.
Table I. Statistical analysis with means and standard deviations for the groups studied.

\begin{tabular}{llll}
\hline Groups & M. Cel/DP & \% V. C. & Stat. \\
\hline Jeltrate & $334.8(82.9)$ & 26.3 & $\mathrm{~A}$ \\
Jeltrate Plus & $797.6(168.2)$ & 62.6 & $\mathrm{~B}$ \\
Jeltrate Chromatic & $484.5(132.6)$ & 38 & $\mathrm{AC}$ \\
Alga Gel & $530.1(74.2)$ & 41.6 & $\mathrm{CD}$ \\
Printer Gel & $387.6(41.6)$ & 30.4 & $\mathrm{ADE}$ \\
Ava Gel & $545.8(100)$ & 42.8 & $\mathrm{CE}$ \\
New Print & $588.8(109)$ & 46.2 & $\mathrm{C}$ \\
Kromopan 100 & $563.7(74.4)$ & 44.2 & $\mathrm{C}$ \\
Tropicalgin & $345.7(42.3)$ & 27.1 & $\mathrm{~A}$ \\
Cavex Orthotrace & $560.8(23.6)$ & 44 & $\mathrm{CE}$ \\
Hydrogum & $651.1(100.5)$ & 51.1 & $\mathrm{BC}$ \\
Orthoprint & $617(173.8)$ & 48.4 & $\mathrm{C}$ \\
Cavex Color change & $559.6(122.2)$ & 43.9 & $\mathrm{C}$ \\
Qualitygel & $319.1(52.4)$ & 25 & $\mathrm{~A}$ \\
C+ & $67(2.20)$ & 5.26 & $\mathrm{~F}$ \\
C- & $1111.5(67.85)$ & 87.31 & $\mathrm{G}$ \\
CC & $1273.75(125.71)$ & 100 & $\mathrm{G}$ \\
\hline
\end{tabular}

$\mathrm{M}$. Cel = mean values for the amount of viable cells; $S D=$ Standard Deviation; \% V.C = percentage viable cells; Stat = Same letters mean no statistical difference. 


\section{DISCUSSION}

Alginate is undoubtedly one of the most accepted materials used in dentistry. The alginate manufacturers produce a powder containing various compounds for different aims. However, many substances such as zinc, barium, cadmium, lead silicates, and fluorides are added to their formulations in order to improve the physical, chemical, and mechanical properties, being a cause of concern in terms of toxicity (de Freitas, 1980).

According to Sydiskis \& Gerhardt, alginate can affect the cell reproduction. That is, this substance may not be toxic enough to kill the cells but can inhibit cell growth, affecting at least the normal cell function. The clinical meaning of this effect is that a single contact with the material may not cause clinical symptoms, whereas repeated contacts may affect the cell viability and consequently cause delayed allergic or toxic reaction. Therefore, the present work aimed at assessing the cytotoxicity of dental alginates in cell cultures.

The use of cell cultures has been widely employed as part of a series of recommended tests to assess the biological behaviour of materials put in contact with human tissues (Estrela, 2005; Jorge et al., 2004; Santos et al., 2008). In the present study, the cytotoxicity of dental alginates was assessed through cytotoxic tests performed with mouse fibroblast L929 cells, a method largely used in several works evaluating the cytotoxicity of materials for use in dentistry (Alcaide et al., 2008; Donadio et al., 2008; Feizzadeh et al., 2008; Jin et al., 2008).

The two-minute evaluation adopted in this study was based on the maximum time in which alginate is left in contact with the oral mucosa during the impression procedure, as recommended by the manufacturer. The samples were kept in contact with culture medium during this 2-minute period, and the supernatants were then put in contact with the cells. The samples were not placed directly upon the cells because mechanical contact between them might damage the cells as suggested by Costa et al. (2001).

The results obtained showed that all alginate materials are cytotoxicity compared to the control groups (CC and C-).

Jeltrate Plus alginate was found to have the higher percentage of viable cells $(62.6 \%)$, whereas Jeltrate one the lowest $(26.3 \%)$. The other alginates had intermediate results.

The lower cell cytotoxicity observed in the Jeltrate Plus alginate can be explained by the absence of lead in this material, a finding also corroborated by Samuel et al. (1995), when they studied the compounds existing in alginates quantitatively and qualitatively. Conversely, Samuel et al. found approximately $0.004 \mathrm{mg} / \mathrm{g}$ of lead in the traditional Jeltrate, which might also be a factor explaining the low cell viability involving this material.

In order to assess the cell response to extreme situations, a positive control group $(\mathrm{C}+)$ was included into this study to cause cell damage. The material used in the positive control group was a non-ionic surfactant (Tween), a toxic agent to biological membranes (Rege et al., 2002), This non-ionic surfactant consists of polyethylene sorbitol fatty acid esters, which is characterised for stimulating protein secretion in microorganisms (Stutzenberger, 1992), for altering both morphology and surface wall of the cells (Domingues et al., 2000). As expected, the positive control group showed high toxicity, being statistically different compared to the other groups $(p<0.05)$.

On the other hand, the negative control group used a PBS solution (phosphate-buffered saline), an acknowledged non-toxic agent, in order to assess only the physical effect on the cells as no other substance was put in contact with the cells. As expected, a low cytotoxicity was observed and no statistical difference found.

It should also be emphasized that a successful clinical dentistry does not involve the technique mastery only, but also requires application of biosecurity norms and attention to the local and systemic consequences produced by dental materials being used. These possible cytotoxic effects should be evaluated in order to improve the security for a given dental material.

In conclusions based on the results obtained, one can conclude that all alginate materials were found to be potentially toxic to cells. It is important to select low-cytotoxicity materials before acquiring new products. 
PITHON, M. M.; DOS SANTOS, R. L.; MARTINS, F. O. \& ROMANOS, M. T. V. Citotoxicidad de alginatos dentales. Int. J. Odontostomat., 4(3):303-308, 2010.

RESUMEN: El alginato o hidrocoloide irreversible, es uno de los materiales de impresión más aceptados y utilizados en odontología. Sin embargo, algunas substancias existentes en estos materiales pueden ser tóxicas. El objetivo de este estudio fue evaluar la citotoxicidad de los alginatos para aplicaciones dentales. Fueron evaluados 14 alginatos diferentes: Jeltrate, Jeltrate Plus, Jeltrate Chromatic, Alga Gel, Printer Gel, Ava Gel, New Print, Kromopan 100, Tropicalgin, Cavex Orthotrace, Hydrogum, Orthoprint, Cavex Color Change y Qualitygel. También se utilizaron tres grupos de control también se utilizaron en este estudio: grupo control positivo $(\mathrm{C}+)$ que consiste en células de detergente Tween 80 , el grupo de control negativo (C-) que consiste en PBS, y el grupo de células de control (CC) que consiste de las células no expuestas. Después de la manipulación de los materiales de acuerdo a las instrucciones del fabricante, las muestras fueron hechas mediante el uso de anillos de silicona. A continuación, las muestras se sumergieron en medio mínimo esencial de Eagle (MEM) durante 2 minutos, seguido de la eliminación de los sobrenadantes y el contacto con los fibroblastos L929. En caso de contacto con el medio, las células fueron incubadas durante 24 horas más en $100 \mathrm{ml}$ de tinción roja neutra al $0,01 \%$. Las células se incubaron nuevamente durante 3 horas para que la tinción pueda ser absorbida. Después de este período, las células fueron fijadas y el recuento de células viables se realizó mediante un espectrofotómetro (BioTek, Winooski, Vermont, EE.UU.) a la longitud de onda de $492 \mathrm{~nm}$. Los resultados demostraron diferencias estadísticamente significativas entre los grupos de CC y C- en relación con los demás $(p<0,05)$. No se observaron diferencias estadísticas entre los grupos Jeltrate Plus y Hydrogum, entre Jeltrate y los grupos Jeltrate Chromatic, Printer Gel, Tropicalgin y Qualitygel, y entre Jeltrate Chromatic y los grupos Alga Gel, Ava Gel, New Print, Kromopan 100, Cavex Orthotrace, Hydrogum, Orhtoprint y Cavex Color Change. Se puede concluir, con base en los resultados de este estudio, que todos los materiales de alginato son citotóxicos.

PALABRAS CLAVE: citotoxicidad, materiales de impresión dental, técnicas de cultivo celular.

\section{REFERENCES}

Alcaide, M.; Serrano, M. C.; Pagani, R.; SanchezSalcedo, S.; Nieto, A.; Vallet-Regi, M. et al. L929 fibroblast and Saos-2 osteoblast response to hydroxyapatite-betaTCP/agarose biomaterial. J. Biomed. Mater. Res. A, 89(2):539-49, 2008.

Anusavice, K. J. Phillips, Materiais Dentários. $11^{\mathrm{a}}$ ed. Rio de Janeiro, Guanabara Koogan S. A., 2005.

Braga, A. S.; Catirse, A. B. C. E. B.; Vaz, L. G. \& Spadaro, A. C. C. Quantitative analysis of potentially toxic metals in alginates for dental use. Rev. Ciênc. Farm. Básica Apl., 26(2):125-30, 2005.

Braga, A. S.; Braga, S. R. S.; Catirse, A. B. C. E. B.; Vaz, L. G. \& Spadaro, A. C. C. Potencial tóxico dos alginatos para uso odontológico. Rev. Ciênc. Farm. Básica Apl., 28(2):153-8, 2007.

Costa, C. A.; Edwards, C. A. \& Hanks, C. T. Cytotoxic effects of cleansing solutions recommended for chemical lavage of pulp exposures. Am. J. Dent., 14(1):25-30, 2001.

de Freitas, J. F. Potential toxicants in alginate powders. Aust. Dent. J., 25(4):224-8, 1980.

Domingues, F. C.; Queiroz, J. A.; Cabral, J. M. \&
Fonseca, L. P. The influence of culture conditions on mycelial structure and cellulase production by Trichoderma reesei Rut C-30. Enzyme Microb. Technol., 26(5-6):394-401, 2000.

Donadio, M.; Jiang, J.; Safavi, K. E. \& Zhu, Q. Cytotoxicity evaluation of Activ GP and Resilon cones in vitro. Oral Surg. Oral Med. Oral Pathol. Oral Radiol. Endod. 106(1):e76-9, 2008.

Estrela, C. Metodologia científica: ensino e pesquisa em odontologia. $2^{a}$ ed. São Paulo, Artes Médicas, 2005.

Feizzadeh, B.; Afshari, J. T.; Rakhshandeh, H.; Rahimi, A.; Brook, A. \& Doosti, H. Cytotoxic effect of saffron stigma aqueous extract on human transitional cell carcinoma and mouse fibroblast. Urol. J., 5(3):1617, 2008.

Jin, C. Y.; Zhu, B. S.; Wang, X. F. \& Lu, Q. H. Cytotoxicity of titanium dioxide nanoparticles in mouse fibroblast cells. Chem. Res. Toxicol., 21(9):1871-7, 2008.

Jorge, J. H.; Giampaolo, E. T. \& Pavarina, A. C. Cytotoxicity of the dental materials. A literature review. Rev. Odontol. UNESP, 33(2):65-8, 2004. 
Neyndorff, H. C.; Bartel, D. L.; Tufaro, F. \& Levy, J. G. Development of a model to demonstrate photosensitizer-mediated viral inactivation in blood. Transfusion, 30(6):485-90, 1990.

Rege, B. D.; Kao, J. P. \& Polli, J. E. Effects of nonionic surfactants on membrane transporters in Caco-2 cell monolayers. Eur. J. Pharm. Sci., 16(4-5):23746, 2002.

Samuel, S. W.; Miranda, L. A. \& Dutra, C. A. V. Potencial Tóxico dos Alginatos. R. Fac. Odontol. Porto Alegre, 36(2):14-6, 1995.

Santos, R. L.; Pithon, M. M.; Oliveira, M. V.; Mendes, G. S.; Romanos, M. T. V. \& Ruellas, A. C. O. Cytotoxicity of introral orthodontic elastics. Braz. J. Oral Sci., 7(24):1520-5, 2008.

Stutzenberger, F. J. Interference of the detergent Tween 80 in protein assays. Anal. Biochem., 207(2):24954, 1992.

Sydiskis, R. J. \& Gerhardt, D. E. Cytotoxicity of impression materials. J. Prosthet. Dent., 69(4):4315, 1993.
Correspondence to:

Matheus Melo Pithon

Av. Otávio Santos, 395, sala 705

Centro Odontomédico Dr. Altamirando da Costa Lima

Bairro Recreio, CEP 45020-750

Vitória da Conquista - Bahia

BRAZIL

Email: matheuspithon@gmail.com

Received: 22-11-2010

Accepted: 01-12-2010 